\title{
3 \\ Kindy and grassroots gender transformations in Solomon Islands
}

\author{
John Cox
}

The Australian National University

\section{Introduction}

Very often in Solomon Islands and other Melanesian countries, ideas of equality between men and women are represented as inherently foreign and incompatible with kastom, the venerable set of social norms that include assemblages of Christian and neotraditional practices and ideals (Douglas 2003; George 2012; Jolly 2000; McDougall 2014). The opposition of women's rights and Melanesian culture is not simply the position of Melanesian traditionalists but is also reproduced by human rights advocates (cf. Hermkens 2013; Monson 2013). This dichotomous reading of complex social phenomena fails to recognise that feminism is hardly a taken-for-granted part of Western culture and that any advances in women's rights in the West or elsewhere are the result of ideological and political struggles that stretch over centuries, taking different forms in different times and places. It also ignores the diverse ways that Melanesian women are engaging with modernity and the initiatives that they are taking to improve their position in society and to make their relationships with men more equal and less prone to violence. As Martha Macintyre 
puts it: 'Attempts to divide women into "westernized" and "traditional" are usually reactionary ploys to discredit the political goals of women' (2000: 167).

In this chapter, I reflect on a recent and short (eight-day) visit to North Vella Lavella, a relatively under-developed part of Western Province in Solomon Islands. My purpose is to draw attention to some small-scale initiatives of women (and men) in rural Melanesia that show proactive (albeit contested) engagements with processes of changing gender relations there. The point is not to romanticise grassroots development by claiming that the kindergarten described provides a model of transformative feminist praxis. Rather, by bringing a humble village kindergarten into view, I hope to open up more options for thinking about the dynamics of social change in Solomon Islands and to unsettle the commonly accepted view that ideologies of male dominance are supported by kastom and are so firmly entrenched in rural areas as to be uncontestable.

\section{Surprising connections in out of the way places}

In November 2014, The Australian National University mobilised several research teams to observe the national elections in Solomon Islands (Cox 2015a). I was a mentor to five Solomon Islanders in the North Vella Lavella Constituency. Vella Lavella is the most north-western of the large islands in the New Georgia Group in Western Province. It is home to some 10,000 people, with about 4,000 living in North Vella. Vella was a heavily contested battlefield during World War II and much of the island's transportation infrastructure dates from that period, including the roads and airstrip in South Vella. The southern half of Vella is close to markets in Gizo, the provincial capital, and so provides better opportunities for cash income than in the North. There is some small-scale cultivation of cocoa and copra, but most who live on Vella rely on subsistence gardening and fishing. Logging companies operate on the island, generating more conflict between clans than payment of royalties (Berg 2008). Formal sector employment is limited to clergy, school teachers and the nurse aids who staff the dilapidated village aid posts. Anyone seriously ill is transported by canoe to Gizo Hospital. 
Our election observation team for North Vella was the only all-male research team, which concerned me as I felt this would limit our access to women's views, even though we surveyed an equal number of women and men during the campaign period and on polling day. This concern was borne out in a number of awkward interviews that I did with (especially younger) women who were painfully shy and who offered only the most minimal answers to our questions. Nevertheless, as is often the case in this type of activity, other unexpected connections and informal relationships that developed in the field provided more access and insight than were elicited by the formal research tools we were using. Similarly, while our explicit purpose was to observe political activities and the formal processes of voting and counting votes, we also had a mandate to contextualise these activities by making wider enquiries and observations. In my case, this included broader questions about economic activity, service delivery, local governance and gender relations.

Arriving in one of the North Vella villages for our pre-poll surveying, our team was introduced to one of several local chiefs, the United Church pastor and the principal of the community high school. These could be seen as three male leadership roles that reflect a commonly perceived set of moral fields in Melanesia: kastom (traditional culture), lotu (Christianity) and gavman (the state and its institutions) (Barker 2007; Burridge 1995; Cox 2015b). The principal and I made eye contact (did he look familiar?) and I introduced myself, shaking hands. He introduced himself as 'Daniel' and asked, 'John, what is your second name?' I replied, 'John Cox' (using my full name because in Solomon Islands I am often known as 'John Cox', spoken as if it were one word). 'I thought so!' he responded. In the subsequent conversations over several days we pieced together the various times we had met over the last decade or longer. The most recent encounter was in 2005 when I had interviewed him in Gizo as part of a project evaluation I was doing as a consultant to the Australian Red Cross. Prior to that, we had met in various schools at which he had taught and where I had placed volunteers as a program manager for Australian Volunteers International, notably Vonunu Provincial Secondary School on South Vella Lavella. Our connections encompassed many of my various engagements with Solomon Islands since my first visit in 1998 and the development of Daniel's own career in education in a number of locations around Western Province. 
I was surprised to find someone that I knew in such an out of the way place but as we talked over the next several days, I was also reminded of how cosmopolitan rural Solomon Islands can be (McDougall 2016) and has always been, with layered interconnections between the islands predating (and intensifying during) the colonial period (Bennett 1987; Dureau 2013; Hviding 2014). Daniel, the community high school principal, has worked in a number of government and church schools around Western Province and, although he lives in a village with few services that is some distance (2-3 hours by outboard motor canoe) from Gizo, he is well connected and well informed, particularly about the education sector. Since leaving Vella, I have had some contact with Daniel by SMS and Facebook, to the extent that he has reviewed a draft of this chapter. These communications are only possible when he visits Gizo or Honiara due to poor connectivity in the village. In this, he is not atypical of other educated villagers. I spoke to several pastors and retired teachers who had worked all over Western Province and in Honiara and who kept up their external connections, including with former Australian volunteers, through letters and mobile phone communication. Many have adult children working in Honiara who send through phone credits or cash to facilitate these links.

\section{A village kindy}

During my stay on North Vella, I was invited to a 'closing ceremony', marking the end of the teaching year for the village 'kindy' (kindergarten), run by Daniel's bright and energetic wife Evelyn. Although this was not central to our election observation brief, I thought it would be illmannered to refuse the invitation. I also hoped that by attending I might get a better feel for how some basic services are delivered in the electorate. The closing ceremony was to be held at the United Church, the largest building in the village. As I entered, I realised this was a big event. The church was full, with about 100 people there, including dozens of small children, their older siblings and proud mothers and fathers. I snuck into the back, trying to be as inconspicuous as possible and hoping simply to observe the proceedings. However, I was soon summoned to sit at the front with the village leadership: the aforementioned community high school principal, pastor and chiefs and the three women who run the kindy. The school chaplain was giving a sermon in Pidjin and English (but not Bilua, the vernacular language of Vella (Berg 2008: 39), nor Roviana, the language of Methodism in the Western Solomons (McDougall 2012). 
This choice of languages is not uncommon. The Sunday worship service I had attended in another village a few days earlier was also conducted in a mix of Pidjin and English, languages that index a register of national and international value, not least that of modern education (Demian 2015).

Soon I was on my feet handing out prizes to about 40 small children, each of whom was called up by name and made to shake my hand before receiving their bag of sweets. The various classes then performed for an audience of parents and relatives, singing songs and reciting poems, the days of the week and months of the year. With prompting from the three women kindy teachers, all of this was done in English. On the one hand, this was cute and appealing. Yet, at another level, by showing off their early adoption of English, the children were performing the modernising value of early childhood education (Glasgow et al. 2011; Jourdan 2007).

Clearly some in the village were not entirely convinced of the need for this new level of schooling (Burton 2012; cf. the male disparagement of women's groups documented by Dureau 1993; McDougall 2016: 117). I had already sensed that some local micro-politics were in play and that I had been conscripted onto the side of education. Therefore I was not entirely surprised when Daniel, who was acting as master of ceremonies, announced to everyone that I was going to give a speech on 'early childhood education'. Those who know me laugh when they hear this story, as there are many others with a much higher level of interest in this topic than me (to say the least). Nevertheless, I knew the kind of thing I should say and so found the words to tell the crowd how I had benefited from two years of kindergarten and a mother who read to me in bed as a small child. Daniel seemed pleased with my performance.

Over the generous feast they had prepared for lunch, I learned just how new the kindy was. Systems for supporting kindergartens and training for teachers of early childhood education have been irregular in Solomon Islands. While some kindy teachers have studied at the University of the South Pacific campus in Honiara, the Solomon Islands College of Higher Education began its first diploma in Early Childhood Education in 2009 as part of a major reform of the sector (Kelly, Daiwo and Malasa 2011). This was only the third year of operation for the North Vella kindy. It has no external funding and the three teachers volunteer their time, even as they are each working on distance-education courses to obtain diplomas in early childhood education. The kindy teachers are all women and two of the three are married to teachers at the community high school or 
primary school. Their husbands are highly supportive of their efforts, often a precondition of success in this kind of environment (Sharp et al. 2015; Spark 2011). In neighbouring villages, news of the kindy has spread and some are thinking about starting their own versions of it. However, thinking about something does not necessarily translate into outcomes and I admired the vision, endeavour and perseverance of my hosts.

That evening, I went up to Daniel's house for dinner. As my colleague and I talked with him, his wife Evelyn (the leader of the kindy), prepared food for us and marshalled children, despite being exhausted from a long day organising the closing ceremony, for which she had also cooked food. I felt rather guilty for not offering to assist in lightening my hostess's 'triple burden' and for making it impossible for her husband to assist her (Pollard 2003). I felt guilty again after dinner for asking her questions about gender issues in Vella. However, I had wanted to speak to her as one of the few educated women that I had access to during my time there and she had agreed to talk with me.

\section{Development and clientelism}

I found the story of the kindy inspiring. Believing in the importance of early childhood education, Evelyn had decided to start a group at her own house and without any funding or resourcing from elsewhere: 'a sole inspirational champion' as Lindsay Burton (2012: 168) describes the chair of a Makira kindergarten. As interest grew, Evelyn enlisted two other teachers and all three of them have started their certificates in early childhood education by distance learning through the Solomon Islands National University (until recently, the Solomon Islands College of Higher Education). This initiative has happened with the support of her husband, the most senior education official in the village, and moves are in place to allow the kindy to be recognised by the Ministry of Education, which will make it eligible for some limited funding. Alice Pollard writes:

many [Solomon Islands] women are visionary and want to implement their vision within their own language or cultural group or with whom they share a common interest such as religious affiliation. Generally they prefer to do so on a voluntary basis (Pollard 2003: 56). 
The kindy certainly exemplifies the capacity of women in rural Solomon Islands to implement their vision locally. However, I believe the voluntary origins of the kindy reflect the limited resources currently available, not the preference for unpaid work that Pollard assumes. In fact, Evelyn was taking steps to formalise and professionalise the kindy by improving her own and her assistants' education standards. She also hoped to become eligible for Ministry of Education funding, even though fully staffed and funded village kindergartens are an unlikely prospect for the time being.

In some ways, the village kindy exemplifies the principles of (neoliberal) participatory development. In the absence of the state, people use their own resources to identify and meet their own needs. However, 'communities' are rarely the innocent and cohesive social groups often assumed by development practitioners (Foale 2001). Here the unspoken subtext was that many of the senior men of the village (and perhaps more conservative women) were a little uncomfortable with women taking the initiative and introducing a new institution over which the men had no control. While child-rearing is routinely understood as women's work, education is a field of public social advancement that bears upon questions of male prestige (McKeown 2001). Hence the need for a legitimating public performance of the value of the kindy that co-opted not only visiting researchers but also village leadership. Held in the village church, the ceremony also included the village pastor and the (well-educated) chaplain of the community high school. The closing ceremony marked the kindy as a key enabler of modern Christian education, something no one could oppose without marking themselves as ignorant, backward or faithless, or perhaps lokol, a Pidjin term of disparagement for those unable to communicate in Pidjin or English (McDougall 2012).

Solomon Islands is a country characterised by very low standards of literacy, even when compared to other Pacific Islands countries. Historically, women there have been excluded from the education system (Strachan 2009). The Ministry of Education and Human Resources Development (MEHRD) reports its disappointment at the very low rates of participation in early childhood education across the country and notes that these are falling behind population growth. If kindergartens are growing rapidly in Solomon Islands (Kelly, Daiwo and Malasa 2011), they are not growing fast enough to meet the needs of a very young population. Nevertheless, given the historic neglect of girls' education, the relatively 
even participation of girls and boys in kindergartens — girls numbered 48.5 percent of kindergarten enrolments in 2013-is encouraging (MEHRD 2013: 22).

In the context of decades of poor service delivery in Solomon Islands and the increasing transfer of public monies into the hands of political patrons, initiating anything new that presumes a public good can be controversial. Politicians may even see themselves as in competition with development programs and they-or their local agents-may see those who seek to improve services as a political threat (Cox 2009). This is because the legitimacy of political patrons is now tied to the normalisation of very low expectations of development. Development in Solomon Islands is not a vision of a prosperous economy or well-resourced schools and hospitals. Rather, it is being redefined as petty political patronage: outboard motors, roofing iron and other minor benefits that are accessed by individuals or heads of households at the whim of politicians or their committees. Other payments may include school fees and medical costs or, particularly around elections, a bag of rice or other small gifts of food or cash. Our observation team heard a number of stories of this nature. Politicians may be criticised as unfair or niggardly distributors of these particularistic benefits but the idea that the MP's primary role is that of distribution is now deeply embedded in Solomon Islands political culture (Cox 2015a).

It was not at all clear from our research on the elections that there was much if any concern about gender inequality in North Vella (Scheyvens 2003; Soaki, this volume). Both men and women expressed little interest in our questions about women standing for election, a hypothetical possibility in a constituency where four men were competing against each other. A number of women indicated that they would be happy for good women candidates to stand in the future but that they would not be likely to vote for them. I interpret this kind of apparently perverse answer as a performance of loyal clientelist citizenship. The women who participated in our surveys were expected to vote for the (male) candidates supported by their families or husbands. Therefore they would not wish to answer questions in ways that could imply disloyalty to a family patron, nor that would imply that they themselves were dishonest: promising to vote for one candidate but telling an interviewer that they would prefer to vote for someone else. In this context of pervasive clientelism, I found Evelyn's commitment to the kindy remarkable. Indeed, it was the only thing happening on North Vella that looked, to my eyes, like 'development'. 


\section{The subversive kindy and changing gender roles}

It will be admitted that a man of slight education and meagre powers can actually teach all that the native, in his present state, needs to know; but when so much depends upon how that little is taught, we see the necessity of the most thorough training. The Pacific is, in reality, only a kindergarten, and its best institutions are only schools for children; but we are recognizing to-day that it needs the best brain to teach children, if they are to reap the fullest advantages of education (Burton 1912: 274).

As the above quotation exemplifies, early missionaries regarded education through a highly condescending and racialised set of beliefs about civilisation. Nevertheless, their flawed interventions_-often based around ideas of 'child rescue' - established much of the educational infrastructure within the region (Young 1989). Although the Methodist Mission established a network of kindergartens in the Western District before World War II (Gina 2003), the oldest kindergarten still operating in Solomon Islands is the YWCA kindy in Honiara. YWCA has a long history of promoting the empowerment of women and girls across the country and the Pacific region, although in Solomon Islands the organisation has only had offices in Honiara and in Munda, Western Province. In the late 1970s, the establishment of YWCA in Munda initially drew considerable resistance from male politicians and the United Church, who saw it as a threat to their own women's groups (Feary and Lai 2012: 45ff). However, these divisions were resolved long ago and YWCA is now very much an accepted part of the church and broader community. Since 1982, YWCA has also run a kindergarten in Munda, which may have influenced Evelyn, as she is a United Church member and has family and work connections to the Munda area.

In speaking with Evelyn, it became apparent that the scope of her work was not merely about giving children in a poorly serviced part of Solomon Islands the opportunity for improved educational outcomes (Gould 2000). Nor was Evelyn motivated by the desire to socialise children into a national polity (Glasgow 2011; Jourdan 1995; Munro 2013) or a transnational middle class (Brison 2009). Other elements of her work that Evelyn explained to me included a broader vision of renewed gender relations quite subversive of the normative hierarchy where women and girls are presumed to be subordinate to men and boys. Solomon Islands girls are widely thought to have no need to learn English if it is expected 
that they will grow up to be village women whose role is not to busy themselves with the decisions of men but to rear children and work in homes and gardens (Dureau 1993).

In this kindy, Evelyn insists that there are no gendered activities, boys and girls do everything together and cooperatively. Evelyn's model of childhood behaviour matches Karen Brison's (2009) description of village kindergartens in Fiji, where gendered divisions between children are not pronounced. Rather than simply regarding the absence of gendered distinctions among young children as a natural state, Evelyn seeks to establish more durable patterns of equitable gender relations. She hopes that this grounding will stay with them as they progress through higher levels of education. She explicitly intends the kindy to provide a formative experience of gender equality and respect for adult women that will shape children, particularly boys, for the rest of their lives.

Kindergartens in Solomon Islands have previously been identified as places where gendered identities can be reformed (e.g. Donnelly 2008). However, the focus of Solomon Islands feminist thinking in the past has been less about reshaping the masculinity of boys and more about liberating women from incessant childcare and allowing them time for work or other interests (Makini 1989; Pollard 2000: 17).

Evelyn's practice is consonant with the growing international interest in working with men to nurture non-violent masculinities that respect women. Her hope that 'when the boys grow up and become men with their own families, they will look after their wives' reflects her attempt to nurture a gentler, more respectful version of masculinity in Solomon Islands. Indeed, the approval and active support given to Evelyn by her husband Daniel indicates that this gentler, more respectful masculinity is already taking shape (Cox and Macintyre 2014). Evelyn's hopes may be better grounded in a kindy run by women where children come to experience women as intelligent leaders than in general village life or in other levels of schooling where the presence of male teachers is likely to provide a different model of gender relations. 


\section{Gender equality, human rights and global cultural flows}

Educated women in urban areas of Melanesia are often regarded as having difficult challenges to face as they try to break out of a conservative set of social constraints that are imagined to characterise Melanesian culture (Macintyre 2011; Spark 2011). Therefore, to find a project like Evelyn's kindy in rural Solomon Islands, particularly one being developed so independently of any external interventions, was surprising. Evelyn and Daniel may not fit popular (and often academic) stereotypes of rural people, in that they are educated and have personal and professional networks that extend well beyond the village context. Perhaps they are more characteristic of the nascent regional middle class (Barbara, Cox and Leach 2015; Brison 2009). And yet their interconnectedness with wider social worlds also characterises more rural people than is often presumed, particularly in Western Solomon Islands (Hviding 2014; McDougall 2016).

Evelyn and Daniel provide an example of the kind of dissemination of global flows of images and ideas, expectations and aspirations, consumer goods and modern dispositions that Charles Taylor has suggested flow into broader society after first being adopted by small circles of elites (Taylor 2004). Indeed, flows of global modernity, particularly those mediated through Christian traditions, do also include ideals of gender equity, albeit inconsistently and in ways that are contested or simply contradicted by other images and practices (Jolly 2000). These changes take place over long periods of time and in Melanesia have a direct lineage that goes back to missionary practices during the colonial era (Dureau 1993; McDougall 2014; Young 1989).

With Macintyre, I have argued that gender relations in Melanesia are changing as a result of such dynamics. In Papua New Guinea, middleclass Pentecostal Christians have cultivated new ideals and practices of marriage that have set a new norm of modern living, initially within a relatively elite group but currently circulating more widely (Cox and Macintyre 2014). Melanesian Christian ideals of marriage also now include nucleated families and companionate romance. These models have implications for the ways men reimagine the standing of their wives and recognise their personhood (Brison 2009; Langmore 1989; Wardlow 2006). 
In the case of the United Church of Solomon Islands there is a formal recognition of the equality of men and women, even though this is hardly reflected in everyday practice (Dureau 1993; Munro, this volume). Nevertheless, from time to time, men may experience personal religious convictions that impel them to reconcile the dissonance between their own behaviour and official church views of proper Christian conduct (Cox and Macintyre 2014). An example of this from the Western Solomons is the (Roviana- and Methodist-born) first Speaker of Parliament, Lloyd Maepeza Gina, who, in his autobiography, thinks it important to recount how his mid-life evangelical reawakening led him to a positive and more respectful revaluing of his wife and family (Gina 2003). Perhaps overoptimistically, I read such professions not as self-serving justifications that mask underlying violence and male privilege, but as rearticulations of social norms that are slowly displacing old ways and making overt male dominance less morally respectable.

Debra McDougall provides another instance of these processes of change in the Western Solomons, noting the 'relatively uncontroversial' admission of women to chief's committees in Ranongga. She argues that although some men still resist human rights and women's rights as foreign intrusions that undermine kastom, 'the constant reiteration of the language of human rights seems to have normalised it' (2014: 203) and has allowed women to exercise new forms of leadership.

Nevertheless, feminist scholars have recognised that international human rights discourses are not straightforwardly emancipatory. They may reinscribe gendered roles that render women as victims. In so doing, women's agency is erased and the fluidity and adaptability of local cultural practices become fixed as oppressive, violent and immutable (Hermkens 2013). Echoing the preoccupations of nineteenth-century missionaries, 'culture' becomes the site of dysfunction and the explanation of why development programs are unsuccessful (Merry 2003). Advocates of women's rights then risk reinforcing a static and patriarchal understanding of local culture.

\section{Kastom and modernity}

I see Evelyn and her husband Daniel as people who selectively embrace innovations from outside the local 'cultural' world that is often supposed to circumscribe normative behaviour in Melanesia. This undermines the oppositional view of 'authentic' Melanesian kastom set against 
'foreign' ideals of women's rights. Where popular accounts of kastom regard it as a primeval unchanging body of traditional practices and roles, anthropologists see in kastom layers of history that reflect not only Melanesian culture but the colonial experience, Christian conversion and contemporary politics. David Akin, in his magisterial study of the Maasina Rule movement, has argued that the historical experience of Malaitans in their struggles against the British colonial government has given rise to a particular ideology of kastom (2013). This Malaitan ideology is 'not an anachronistic longing for the past, or an attempt to preserve or revive lost traditions per se, but rather a modern and evolving political philosophy born from the colonial and postcolonial experience' (ibid.: 342).

Malaitan kastom, like kastom all over Melanesia, is therefore dynamic and political, not a nostalgic longing for past ways. Kastom plays out in subtly different ways around the country, not least in the ways that particular versions of kastom are employed to police women's behaviour and the conduct of men towards women. Malaitan kastom is seen by many Solomon Islanders to be more patriarchal and more insistent on sexual propriety. This can lead to disputes over matters such as bridewealth when Malaitans interact with people from other traditions. As Malaita has become a defined 'other' for many in Western Province and especially Guadalcanal, these differences have become more fixed and emblematic of the oppositional identities that have become the ideological drivers of the 1998-2003 civil unrest (Allen 2013). However, McDougall (2016: 196-207) argues that disputes over sexual improprieties and so forth are not the result of clashes between incompatible cultural systems. Rather, such disputes are common even within supposedly homogeneous groups and so conflict between Ranonggans and Malaitans is in practice resolved within comparable kastom frameworks.

Kastom always involves an engagement with modern ideas and systems. As Matthew Allen et al. note, 'Kastom systems do not function independently from the other systems under discussion, including the state' (2013: 34). Indeed, as McDougall notes for Ranongga, customary institutions such as chiefs' committees are 'better viewed as the last remnant of a colonial system of indirect rule neglected by a postcolonial state' (2014: 217). Kastom is not always institutionalised in roles such as chiefs but is often articulated as a moral reference point. Benedicta Rousseau (2008) interprets kastom in Vanuatu as a mode of right conduct or a tool for the judgement of proper behaviour that incorporates Christianity and other modern institutions and situations without necessarily making a strong 
claim to indigeneity. She argues that, 'With few exceptions, Christian principles are viewed as a core part of indigenous identity, and previously perceived incompatibilities between kastom and Christianity have been ironed out (or at least smoothed over)' (2008: 16). This 'ironing out' or 'smoothing over' has been happening for a long time in Western Solomon Islands. Part of this integration of an older indigenous tradition with Christianity has included a very active acceptance of modern education.

\section{Rights, education and culture}

Contemporary ideas and practices of education, particularly early childhood education, contain an implied gender equality in their commitment to developing the modern social and educational skills of individual children even as they inculcate social norms that index a global middle class (Brison 2009). This is not to deny the pervasive practices in society at large that discriminate against women and girls, not least in educational systems. Brison (2009), for example, argues that middle-class kindergartens in urban Fiji intensify the processes by which children come to identify with stereotypical gender roles for girls and boys. These serious injustices notwithstanding (or perhaps because of them), the underlying principles of gender equity seem to be visible, intelligible and attractive to at least some women in rural Solomon Islands. Some are finding ways of acting out ideals of gender equity as they also strive to achieve other objectives. Rather than seeing villages as bastions of pre-modern tradition-particularly as places of immutable misogynist tradition where the very idea of gender equality is a foreign imposition fundamentally irreconcilable with local cultural norms-academics, development practitioners and advocates for gender equity should be conscious of the ways in which global cultural flows are being appropriated by women and men in unlikely places and with potentially transformative effects.

Burton (2012) has documented a project of cultural rejuvenation through early childhood education in Makira Province. Her research examines a successful kindergarten, run by members of the South Seas Evangelical Church (SSEC) and grounded in respect for indigenous values. The SSEC kindy is one way in which its community are responding to their anxieties of 'intergenerational cultural decay' in the face of economic change (Tepahae 1997). Burton contrasts the SSEC kindergarten with a kindy in a Church of Melanesia community dominated by what 
she sees as individualistic values that undermine cultural values and communitarian efforts to maintain a public good. This is a somewhat surprising finding given the historical predisposition of the Church of Melanesia to incorporate indigenous culture and language into worship (Hilliard 1978). The SSEC, by contrast, have tended to be more explicitly committed to (Christian) modernisation, often hostile to traditional practices and active in their use of English and Pidjin (Watson-Gegeo and Gegeo 1991).

The colonial and postcolonial history of Western Province is quite different from that of Malaita or Makira and continues to shape the ways that Western Province people engage with modern ideas, institutions and practices. Western Province had a very different experience of labour recruiting and plantations and the Methodist and Seventh-day Adventist churches have shaped the western regional identity quite differently from the Anglicans and SSEC in the Eastern Solomons (Bennett 1987; Dureau 2008).

The North Vella kindy does not appear to exhibit the dynamics that Burton describes in cultural terms. In Vella, Western knowledge and pedagogy were not problematised, nor was there an explicit commitment to integrating Western and indigenous knowledge practices. Rather, at least in the form displayed to the village in the closing ceremony, the kindy modelled itself as an effective induction into Western schooling and particularly the modern life skills of English language, literacy, numeracy and measurement of time in days and months (Makini 1989). As far as I could tell, this was not seen as a threat to the indigenous culture of the area, perhaps because of earlier shifts within the United Church where the transition from the Methodist Mission to the United Church of Papua New Guinea and Solomon Islands (1968) expanded the scale at which the church operated from the regional Roviana-speaking Western Solomons to a transnational level where English played a more important role (Hviding 1996; McDougall 2012).

In many cases, cultural narratives of the failure of development in the Pacific founder in the face of comparative evidence (Haque 2012). Such narratives are not always imposed from the outside. They can also be seen as ideological products of indigenous elites who have already captured the benefits of education and other services and economic opportunities and seek to justify their position by arguing that the 'innocent population' of Melanesian subsistence horticulturalists has no real need of such Western 
impositions (Golub 2014; Hau'ofa 1987). These views often entail condescending and oppressive views of the place of women in society and may seek to 'protect' women from the corrupting and destabilising influence of 'foreign' ideas such as women's rights or gender equity (George 2012; Taylor 2008).

In practice, Melanesians are as likely to look for ways of bringing the modern and the cultural together as to insist that the two are opposed. One evening, Daniel asked me what I thought of human rights. This was a lead into discussing the difficult issue of the corporal punishment of children, a practice officially banned in Solomon Islands schools but retaining considerable popular legitimacy. Daniel saw child rights as a part of the 'whiteman culture that is coming in, where if you beat your children I'll report you to the police'. However, this process for him was not about reinforcing a popular narrative of cultural loss or 'intergenerational cultural decay' (Burton 2012). While he contrasted 'whiteman' (Cox 2015b) and Melanesian cultures, this was at the level of practice and did not mark out two incompatible cultural domains. As far as Daniel was concerned, his society was undergoing a transition where practices were changing for the better but the process of change has created problems - such as new modes of disciplining children-that need to be addressed proactively. In his mind, these are management issues, not a fundamental clash of cultural values.

Nor was he personally threatened by the new paradigm, as some men have been (Taylor 2008). Indeed, as the quotes from Iriqila (a large village in North Vella Lavella) reproduced by Pauline Soaki (this volume) indicate, Solomon Islands women themselves often find rights discourse troubling and frame it in opposition to kastom. Daniel himself accepted the desirability of new non-violent practices in the school but was concerned about disciplinary issues, now that 'children don't worry because there's no big punishment' (in the absence of physical punishment). He told me about his way of managing discipline by initiating dialogues between parents, children and teachers. He saw dialogue as a means of easing tensions over different understandings of discipline as well as addressing specific aspects of children's misbehaviour while at school.

As with Evelyn's initiative in setting up the kindy, training herself and other teachers and accessing other resources, Daniel's school management practices represent a pragmatic engagement with the highly desirable good of modern education. However, this commitment does not rest 
on an ideological rejection of the customary as backward, primitive or sinful. If there is a cultural humiliation underlying their desire for change (Sahlins 1992), it is far from apparent. Rather, there is a curiosity and an ambivalent openness to both the customary past and the modern future (Dureau 2014). As the active involvement of chiefs and pastors in the kindy closing ceremony indicates, Daniel and Evelyn seem able to work with kastom, lotu and gavman (the three points of moral orientation outlined by Burridge 1995) in the same frame, mobilising all sources of support and validation for their developmental project. Indeed, Daniel himself is now preparing for a chiefly role within his own island community and has asked me to supply him with relevant ethnographic materials. He is particularly interested in the writings of A.M. Hocart whose 1908 research in Simbo, Vella and other islands is held to be a valuable historical resource by many contemporary Western Solomon Islanders (Hviding and Berg (eds) 2014).

\section{Conclusion}

The widespread engagement of Pacific Islanders with modern institutions, ideas and practices is recognised by anthropologists as a complex process that involves degrees of agency, encompassment, resistance and appropriation (LiPuma 2000; Sahlins 1992). If Pacific Islanders embrace modern institutions, such as Christianity or educational systems, they may do so on their own terms and for their own reasons. This does not require them to surrender their cultural integrity or make a Sisyphean commitment to inevitable failure in their repeated attempts to reconcile an essential incompatibility between indigenous and Western cultural values and ways of being.

Across the Pacific (and beyond), the flashpoints of local politics of tradition are often found in arguments about the proper place and conduct of women. These debates can appear reactionary to those who take Western liberal democratic traditions as a global norm (notwithstanding the ongoing sexism in Australia and other developed countries that are presumed to provide a model for developing states). In drawing attention to the North Vella kindergarten, my intention has been to show how ordinary Melanesians are negotiating these debates about changing gender roles. Evelyn and her husband Daniel provide examples not of feminist revolutionary activists, but of progressive educationalists who 
have fostered an acceptance of women's initiative in a very conservative environment. In doing so, they have gently inserted practices of gender equality into local narratives of development. They have done so without allowing their agenda to be lost in fruitless debates about kastom where cultural integrity is defined in ways that make women subservient to men. Rather, they have operated in the 'emerging cracks in neo-traditional forms of patriarchy' (McDougall 2014: 203). While they are hardly calculating people, their modest, shrewd and subtle means of working for change may provide something of a model for others who seek the same ends.

\section{References}

Akin, David. 2013. Colonialism, Maasina Rule and the Origins of Malaitan Kastom. Honolulu: University of Hawai i Press. doi.org/10.21313/ hawaii/9780824838140.001.0001.

Allen, Matthew. 2013. Greed and Grievance: Ex-Militants' Perspectives on the Conflict in Solomon Islands, 1998-2003. Honolulu: University of Hawai'i Press. doi.org/10.21313/hawaii/9780824838546.001.0001.

Allen, Matthew, Sinclair Dinnen, Daniel Evans and Rebecca Monson. 2013. Justice Delivered Locally: Systems, Challenges and Innovations in Solomon Islands. Research Report, Justice for the Poor, New York: The World Bank.

Barbara, Julien, John Cox and Michael Leach. 2015. 'The emergent middle classes in Timor-Leste and Melanesia: Conceptual relevance and identification'. State, Society and Governance in Melanesia, discussion paper 2015/4. Canberra: The Australian National University.

Barker, John. 2007. 'All sides now: The postcolonial triangle in Uiaku'. In The Anthropology of Morality in Melanesia and Beyond, ed. John Barker, pp. 75-91. Aldershot and Burlington: Ashgate.

Bennett, Judith. 1987. Wealth of the Solomons: A History of a Pacific Archipelago, 1800-1978. Honolulu: University of Hawai' i Press.

Berg, Cato. 2008. 'A chief is a chief wherever he goes: Land and lines of power in Vella Lavella, Solomon Islands'. PhD dissertation, University of Bergen. 
Brison, Karen. 2009. 'Shifting conceptions of self and society in Fijian kindergartens'. Ethos 37(3): 314-33. doi.org/10.1111/j.15481352.2009.01055.x.

Burridge, Kenelm. 1995 [1960]. Mambu: A Melanesian Millennium. Princeton: Princeton University Press. doi. org/10.1515/9781400851584.

Burton, John Wear. 1912. The Call of the Pacific. London: Charles H. Kelly.

Burton, Lindsay. 2012. 'Building on living traditions: Early childhood education and culture in Solomon Islands'. Current Issues in Comparative Education 15(1): 157-75.

Cox, John. 2015a. 'The politics of distribution in Solomon Islands: North Vella Lavella constituency'. State, Society and Governance in Melanesia, in brief 2015/1. Canberra: The Australian National University.

- - 2015b. 'Israeli technicians and the postcolonial racial triangle in Papua New Guinea'. Oceania 85(3): 342-58. doi.org/10.1002/ ocea. 5100 .

- 2009. 'Active citizenship or passive clientelism? Accountability and development in Solomon Islands'. Development in Practice 19(8): 96480. doi.org/10.1080/09614520903220784.

Cox, John and Martha Macintyre. 2014. 'Christian marriage, money scams and Melanesian social imaginaries'. Oceania 84(2): 138-57. doi.org/10.1002/ocea.5048.

Demian, Melissa. 2015. 'Dislocating custom'. Political and Legal Anthropology Review 38(1): 91-107. doi.org/10.1111/plar.12088.

Donnelly John. 2008. Early Childhood Education: A Solid Foundation in the Solomon Islands. The Girl Child Reading and Rescue Project. Melbourne: World Vision Australia.

Douglas, Bronwen. 2003. 'Christianity, tradition and everyday modernity: Towards an anatomy of women's groupings in Melanesia'. Oceania 74(1-2): 6-23. doi.org/10.1002/j.1834-4461.2003.tb02833.x. 
Dureau, Christine. 2013. 'Visibly black: Phenotype and cosmopolitan aspirations in Simbo, Western Solomon Islands'. In Senses and Citizenships: Embodying Political Life, ed. Susanna Trnka, Christine Dureau and Julie Park, pp. 33-54. New York and London: Routledge.

— 2008. 'Decreed affinities: Nationhood and the Western Solomon Islands'. Journal of Pacific History 33(2): 197-220.

—. 1993. 'Nobody asked the mother: Women and maternity on Simbo, Western Solomon Islands'. Oceania 64(1): 18-35. doi. org/10.1002/j.1834-4461.1993.tb02445.x.

Feary, Sue and Jocelyn Lai. 2012. Stori blo YWCA: A History of the Young Women's Christian Association in Solomon Islands. Honiara: Solomon Islands YWCA.

Foale, Simon. 2001. 'Where's our development? Land-owner expectations and environmentalist agendas in Western Solomon Islands'. The Asia Pacific Journal of Anthropology 2(2): 44-67. doi.org/10.1080/144422 10110001706105.

George, Nicole. 2012. Situating Women: Gender Politics and Circumstance in Fiji. Canberra: ANU E Press. Online: press.anu.edu.au/publications/ situating-women (accessed 12 August 2016).

Gina, Lloyd Maepeza. 2003. Journeys in a Small Canoe: The Life and Times of a Solomon Islander. Canberra: Pandanus Press.

Glasgow, Ali. 2011. 'Curriculum development in early childhood development: Cook Islands and Solomon Islands'. In Harvesting Ideas: Perspectives from a Niu Generation of Pacific Leaders, ed. Kabini Sanga and Joanna Kidman, pp. 148-63. Suva: University of South Pacific Press.

Glasgow, Ali, Bernadine Ha'amori, Joanna Daiwo and Viola Malasa. 2011. 'The Solomon Islands initiatives to support and enhance the use of vernaculars in early childhood education'. Language and Linguistics in Melanesia 29: 87-94.

Golub, Alex. 2014. Leviathans at the Gold Mine: Creating indigenous and corporate actors in Papua New Guinea. Durham, NC: Duke University Press. doi.org/10.1215/9780822377399. 
Gould, Diana. 2000. 'The relationship between early childhood education and primary school academic achievement in Solomon Islands'. International Journal of Early Childhood 32(1): 1-8. doi.org/10.1007/ BF03169016.

Haque, Tobias. 2012. 'Influence of culture on economic development in Solomon Islands: A political-economy perspective'. State, Society and Governance in Melanesia, discussion paper 2012/1. Canberra: The Australian National University.

Hau'ofa, Epeli. 1987. 'The new South Pacific society: Integration and independence'. In Class and Culture in the South Pacific, ed. Anthony Hooper, Steve Britton, Ron Crocombe, Judith Huntsman and Cluny Macpherson, pp. 1-15. Auckland: University of Auckland and Suva: University of the South Pacific.

Hermkens, Anna-Karina. 2013. “'Raits blong mere”? Framing human rights and gender relations in Solomon Islands'. Intersections: Gender and Sexuality in Asia and the Pacific 33. Online: intersections.anu.edu. $\mathrm{au} /$ issue33/hermkens.htm (accessed 18 June 2016).

Hilliard, David. 1978. God's Gentlemen: A History of the Melanesian Mission, 1849-1942. St Lucia: University of Queensland Press.

Hviding, Edvard. 2014. 'Across the New Georgia Group: A.M. Hocart's fieldwork as inter-island practice'. In The Ethnographic Experiment: A.M. Hocart and W.H.R. Rivers in Island Melanesia, 1908, ed. Edvard Hviding and Cato Berg, pp. 71-107. Oxford and New York: Berghahn Books.

—_. 1996. Guardians of Marovo Lagoon: Practice, Place, and Politics in Maritime Melanesia. Honolulu: University of Hawai'i Press.

Hviding, Edvard and Cato Berg (eds). 2014. The Ethnographic Experiment: A.M. Hocart and W.H.R. Rivers in Island Melanesia, 1908. Oxford and New York: Berghahn Books.

Jolly, Margaret. 2000. “Woman ikat raet long human raet o no?" Women's rights, human rights and domestic violence in Vanuatu'. In Human Rights and Gender Politics: Asia-Pacific Perspectives, ed. Anne-Marie Hilsdon, Martha Macintyre, Vera Mackie and Maila Stivens, pp. 120-42. London and New York: Routledge. 
Jourdan, Christine. 2007. 'Linguistic paths to urban self in postcolonial Solomon Islands'. In Consequences of Contact: Language Ideologies and Sociocultural Transformations in Pacific Societies, ed. Miki Makihara and Bambi Schieffelin, pp. 30-48. Oxford: Oxford University Press. doi.org/10.1093/acprof:oso/9780195324983.003.0002.

- 1995. 'Stepping-stones to national consciousness: The Solomon Islands case'. In Nation-Making: Emergent Identities in Postcolonial Melanesia, ed. Robert Foster, pp. 127-50. Ann Arbor: University of Michigan Press.

Kelly, Janette, Joanne Daiwo and Viola Malasa. 2011. 'Funds of knowledge: Developing a diploma in teaching in early childhood education in the Solomon Islands'. Waikato Journal of Education 16(2): 71-83. doi. org/10.15663/wje.v16i2.52.

Langmore, Diane. 1989. 'The object lesson of a civilised, Christian home'. In Family and Gender in the Pacific: Domestic Contradictions and the Colonial Impact, ed. Margaret Jolly and Martha Macintyre, pp. 84-94. Cambridge: Cambridge University Press. doi.org/10.1017/ CBO9781139084864.005.

LiPuma, Edward. 2000. Encompassing Others: The Magic of Modernity in Melanesia. Ann Arbor: University of Michigan Press.

Macintyre, Martha. 2011. 'Money changes everything: Papua New Guinean women in the modern economy'. In Managing Modernity in the Western Pacific, ed. Mary Patterson and Martha Macintyre, pp. 90-120. St Lucia: University of Queensland Press.

—. 2000. "'Hear us, women of Papua New Guinea!" Melanesian women and human rights'. In Human Rights and Gender Politics: Asia-Pacific Perspectives, ed. Anne-Marie Hilsdon, Martha Macintyre, Vera Mackie and Maila Stivens, pp. 147-71. London and New York: Routledge.

Makini, Jully. 1989. 'A YWCA kindergarten in the Solomon Islands'. Summary of a presentation given at the workshop, Women, Development and Empowerment: A Pacific Feminist Perspective, Fiji, March 1987. Online: nzetc.victoria.ac.nz/tm/scholarly/teiGriWom2-c2-4.html (accessed 17 August 2016). 
McDougall, Debra. 2016. Engaging with Strangers: Love and Violence in the Rural Solomon Islands. ASAO Studies in Pacific Anthropology, vol. 6. New York and Oxford: Berghahn.

—_. 2014. "'Tired for nothing": Women, chiefs, and the domestication of customary authority in Solomon Islands'. In Divine Domesticities: Christian Paradoxes in Asia and the Pacific, ed. Hyaeweol Choi and Margaret Jolly, pp. 199-224. Canberra: ANU Press. Online: press. anu.edu.au/publications/divine-domesticities (accessed 12 August 2016).

- 2012. 'Stealing foreign words, recovering local treasures: Bible translation and vernacular literacy on Ranongga (Solomon Islands)'. The Australian Journal of Anthropology 23(3):318-39. doi.org/10.1111/ taja.12003.

2003. 'Fellowship and citizenship as models of national community: United Church Women's Fellowship in Ranongga, Solomon Islands'. Oceania 74(1-2): 61-80.

McKeown, Eamonn. 2001. 'Biros, books and big-men: Literacy and the transformation of leadership in Simbu, Papua New Guinea'. Oceania 72(2): 105-16. doi.org/10.1002/j.1834-4461.2001.tb02775.x.

Merry, Sally Engel. 2003. 'Human rights law and the demonization of culture (and anthropology along the way)'. Political and Legal Anthropology Review 26(1):55-76. doi.org/10.1525/pol.2003.26.1.55.

Ministry of Education and Human Resources Development (MEHRD). 2013. MEHRD Performance Assessment Report 2006-2013. Honiara: Ministry of Education and Human Resources Development.

Monson, Rebecca. 2013. 'Vernacularising political participation: Strategies of women peace-builders in Solomon Islands'. Intersections: Gender and Sexuality in Asia and the Pacific 33. Online: intersections. anu.edu.au/issue33/monson.htm (accessed 18 June 2016).

Munro, Jenny. 2013. 'The violence of inflated possibilities: Education, transformation and diminishment in Wamena, Papua'. Indonesia 95: 25-46. doi.org/10.1353/ind.2013.0008. 
Pollard, Alice Aruhe'eta. 2003. 'Women's organizations, voluntarism, and self-financing in Solomon Islands: A participant perspective'. Oceania 74(1-2): 44-60.

- 2000. Givers of Wisdom, Labourers Without Gain: Essays on Women in Solomon Islands, ed. Anthony Walker. Suva: Institute of Pacific Studies, University of the South Pacific.

Rousseau, Benedicta. 2008. "This is a court of law, not a court of morality": Kastom and custom in Vanuatu state courts'. Journal of South Pacific Law 12(2): 15-27.

Sahlins, Marshall. 1992. 'The economics of develop-man in the Pacific'. Res 21: 12-25. doi.org/10.1086/resv21n1ms20166839.

Scheyvens, Regina. 2003. 'Church women's groups and the empowerment of women in Solomon Islands'. Oceania 74(1-2): 24-43. doi. org/10.1002/j.1834-4461.2003.tb02834.x.

Sharp, Timothy, John Cox, Ceridwen Spark, Stephanie Lusby and Michelle Rooney. 2015. 'The formal, the informal and the precarious: making a living in urban Papua New Guinea'. State Society and Governance in Melanesia, discussion paper 2015/2. Canberra: The Australian National University.

Spark, Ceridwen. 2011. 'Gender trouble in town: Educated women eluding male domination, gender violence and marriage in Papua New Guinea'. The Asia-Pacific Journal of Anthropology 12(2): 164-79. doi.or g/10.1080/14442213.2010.546425.

Strachan, Jane. 2009. 'Women and educational leadership in New Zealand and Melanesia'. In Women Leading Education Across the Continents: Sharing the Spirit, Fanning the Flame, ed. Helen Sobehart, pp. 100-109. Lanham, MA: Rowman and Littlefield Education.

Taylor, Charles. 2004. Modern Social Imaginaries. Durham, NC: Duke University Press.

Taylor, John. 2008. 'The social life of rights: "Gender antagonism", modernity and raet in Vanuatu'. The Australian Journal of Anthropology 19(2): 165-78. doi.org/10.1111/j.1835-9310.2008.tb00120.x. 
Tepahae, Philip. 1997. 'Chiefly power in Southern Vanuatu'. State, Society and Governance in Melanesia, discussion paper 1997/9. Canberra: The Australian National University.

Wardlow, Holly. 2006. 'All's fair when love is war: Romantic passion and companionate marriage among the Huli of Papua New Guinea'. In Modern Loves: The Anthropology of Romantic Courtship and Companionate Marriage, ed. Jennifer Hirsch and Holly Wardlow, pp. 51-77. Ann Arbor: University of Michigan Press.

Watson-Gegeo, Karen and David Gegeo. 1991. 'The impact of church affiliation on language use in Kwara'ae (Solomon Islands)'. Language in Society 20: 533-55. doi.org/10.1017/S0047404500016717.

Young, Michael. 1989. 'Suffer the children: Wesleyans in the D'Entrecasteux'. In Family and Gender in the Pacific: Domestic Contradictions and the Colonial Impact, ed. Margaret Jolly and Martha Macintyre, pp. 108-35. Cambridge: Cambridge University Press. doi. org/10.1017/CBO9781139084864.007. 
This text is taken from Transformations of Gender in Melanesia, edited by Martha Macintyre and Ceridwen Spark, published 2017 by ANU Press, The Australian National University, Canberra, Australia. 